Subscription $\$ 2.00$ per Volume

THE TREE-RING BULLETIN

Editor . . . . Bryant Bannister Assistant Editors . . J. L. Giddings Erik Holmsgaard Harold C. Fritts
THE TREE-RING SOCIETY

President . . . John C. Mc.Gregor

Secretary-Treasurer . C. W. Ferguson

Manuscripts and inquiries should be directed to the Laboratory of Tree-Ring Research, University of Arizona, Tucson, Arizona.

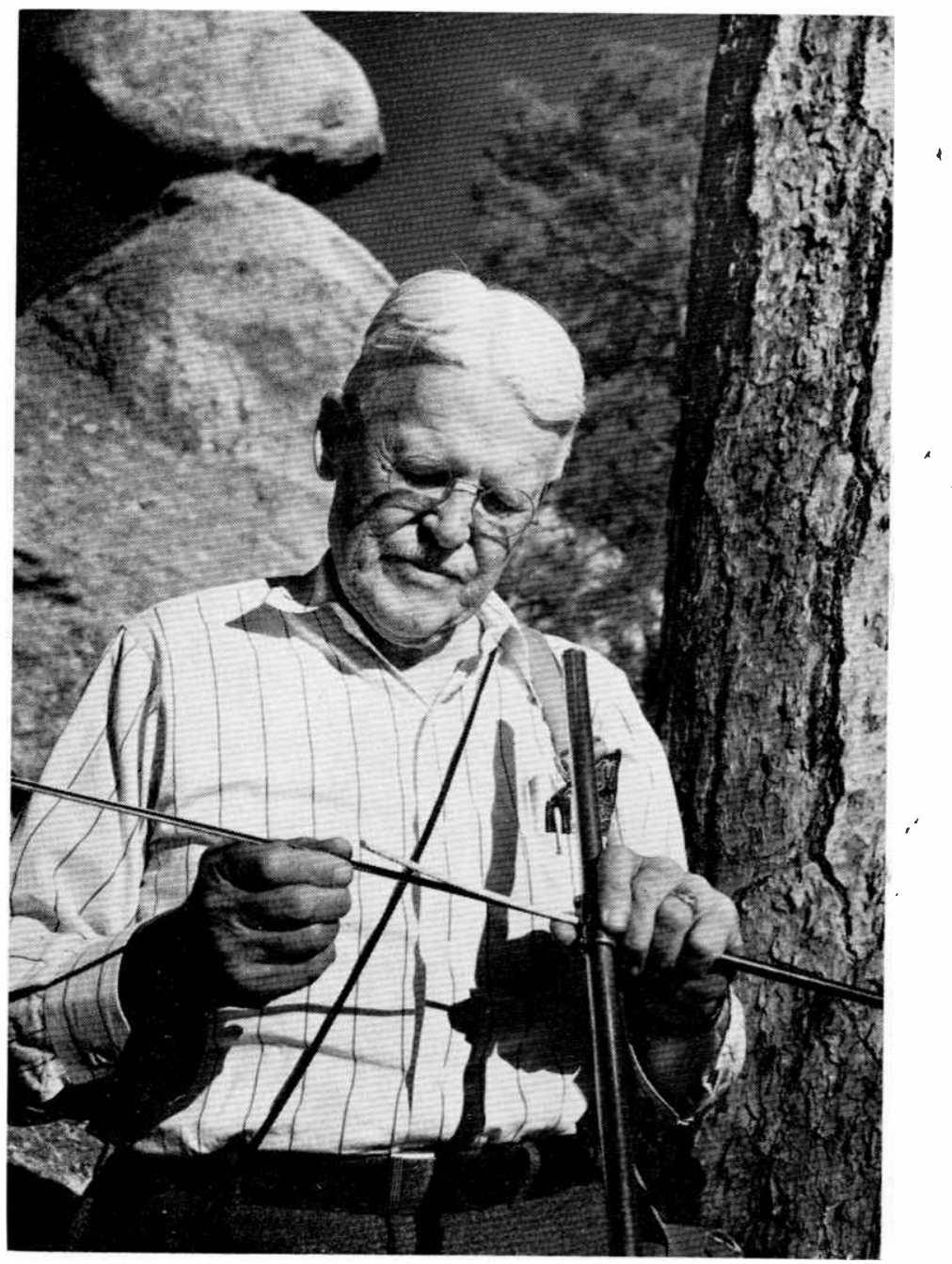

Charles W. Herbert, Western Ways

ANDREw Ellicott Douglass 


\section{ANDREW ELLICOTT DOUGLASS}

\section{7-1962}

Andrew Ellicott Douglass died March 20, 1962, in Tucson, Arizona, at the age of 94. It can be said that he lived as full and productive a life as any man of this era. To some, he will be remembered as an astronomer of the first magnitude, to others he was a physicist, a philosopher, an inventor, a judge, a mountain climber, a college president-and to all a scientist and teacher. But to readers of the Tree-Ring Bulletin, Douglass will be remembered as the father of dendrochronology. It cannot be said that he created tree-ring research, but it can be truly stated that he pioneered, developed, and stimulated the study and application of tree-ring data.

Douglass was born in Windsor, Vermont, on July 5, 1867, the son of the Reverend Malcolm and Sarah E. (Hale) Douglass. He grew up in New England and attended Trinity College in Connecticut. In later years, he often cited his New England heritage as responsible for his first interest in tree-rings; the contrast between the moist country of his childhood and the arid Southwest aroused his curiosity as to what story the rings of trees might tell. After graduating with the B.A. degree in 1889, he started his career in astronomy as an assistant in the Harvard College Observatory, a position he held until 1894. During this time he spent several years as a member of the Harvard Expedition to Peru, where, in addition to helping decide the site of the Peruvian Station of the Harvard College Observatory near Arequipa, he became the first man to measure the rate of movement of Peru's famous cresentic sand dunes.

In 1894, at the request of Percival Lowell, Douglass selected the location for the Lowell Observatory in Flagstaff and became First Assistant at the observatory. Traveling by buckboard across the then wild Territory of Arizona, he became familiar with the country he was to know so intimately in future years. In the beginning of the twentieth century, Douglass served three years as Probate Judge for Coconino County (1903-1906), and taught at Northern Arizona Normal, now Arizona State College at Flagstaff, in 1905 and 1906. It was during this period that he married Ida E. Whittington, in 1905.

Douglass moved to the University of Arizona in 1906 and remained as a member of the faculty until his death. He began as Assistant Professor of Physics and Geography and advanced to Professor of Physics and Astronomy a year later, a title held until 1922. In 1910 and 1911, he served as Acting President of the University, and from 1915 to 1917, as Dean of the College of Letters, Arts, and Sciences. After designing and being instrumental in the establishment of Steward Observatory, he became its first director in 1917. Here it was that tree-ring specimens and telescopes existed side by side and Douglass' mastery of two sciences brought world-wide attention. In 1936, the title of Professor of Dendrochronology was added and he became Director of the newly established Laboratory of Tree-Ring Research in 1938. Also in 1938, he became Director Emeritus of the Steward Observatory but returned as Acting Director during the war years 19421946. From 1946 to 1958, he was Director Emeritus of the Steward Observatory; Director of the Laboratory of Tree-Ring Research; Professor of Astronomy and Dendrochronology half-time; and, after 1958, he also became Director Emeritus of the Tree-Ring Laboratory, continuing all assignments on a part-time basis.

To trace the beginnings of Douglass' tree-ring work, one must go back to 1901 when, seeking an answer to the problem of extending sun-spot records into the past, he turned to trees as possible recorders of solar phenomena. During these early years in Flagstaff, Douglass examined 
scores of ring series, often traveling out to lumbering areas and making crude rubbings from the tops of freshly cut stumps. A portent of future events came about in 1904 when Douglass recognized a characteristic ring pattern in an old stump and confidently announced the year in which the tree had been felled-much to the amazement of the farmer who had done the cutting. By 1907 a considerable group of Flagstaff trees had been studied and measured and the results were published in 1909 , the first of Douglass' long list of tree-ring citations. He had thoroughly committed the Flagstaff ring series to memory and it came as a revelation when in 1911 he recognized the same ring patterns occurring in trees near Prescott. When the significance of the crossdating principle was fully realized, Douglass turned to his tree-ring research with the exceptional vigor that characterized his entire scientific career. He collected and studied groups of trees in northern Europe and then from 1915 to 1919 focused his attention on the giant sequoias of California, hoping at the time that their chronologies would crossdate with the trees of northern Arizona. A major summary report of all his tree-ring work to that date, "Climatic Cycles and TreeGrowth, Volume I" was published in 1919 by the Carnegie Institution of Washington.

Meanwhile, an odd alliance with a field far removed from astronomy was beginning to take form. Clark Wissler of the American Museum of Natural History heard Douglass talk at a Washington meeting in 1914 and a few years later arranged to have Douglass look at some wood samples from prehistoric ruins in New Mexico. Douglass evidently liked what he saw, for in 1919 he received six additional beam sections collected from Aztec Ruin in New Mexico by Earl H. Morris and promptly announced that the Aztec specimens crossdated with each other. The next step followed a year later when Douglass studied some Pueblo Bonito logs and quickly determined that they too could be crossdated with the Aztec pieces and, in fact, the relative time relationship of the two ruins could be stated. This was exciting news indeed to the archaeologists and there then began an association between Douglass and the archaeological profession, helped along by the National Geographic Society, which attained its highest point in 1929 with the successful dating of Pueblo Bonito and the assignment of absolute dates to some forty other major ruins in the Southwest.* The Pueblo Bonito Dating Project, described in detail in Douglass' 1935 publication, "Dating Pueblo Bonito and Other Ruins of the Southwest," stands as one of the finest examples of inter-disciplinary cooperation in the annals of American archaeology.

The relationship of Southwestern tree-growth and climate also received early attention by Douglass. His 1914 paper on a method of estimating rainfall by the growth of trees was but the first of his many publications on this subject. Greatly amplified and extended by his students, notably the late Edmund Schulman, the still expanding field of dendroclimatology has become one of the most important aspects of tree-ring research.

In addition to his other activities, Douglass maintained his keen interest in sunspots and weather cycles throughout his life. To those who knew him well, it often appeared that he considered his tree-ring work as no more than a convenient way of gathering data for cycle studies and his successful venture into archaeological dating as but a brief interlude in his search for understanding solar-terrestrial relationships. By the 1940's, when Edmund Schulman had capably taken on the bulk of dendroclimatic investigations and archaeological tree-ring dating was being practiced in several institutions by a score of former students, Douglass was devoting

\footnotetext{
*A first-hand account of the dramatic conclusion reached in 1929 is given by Emil W.
} Haury in the following article of this issue. 
nearly all of his research time to the quest for a method of long-range weather prediction-a problem he saw in terms of solar cycles affecting the meteorological patterns of Earth's atmosphere. Early in his work he constructed the ingenious cycloscope, an instrument designed to optically analyze tree-ring and other time-series data for cyclic content. Later, when in his late 80's, Douglass designed a complex planetary interpolator to aid in his investigation of planetary-solar relationships. It is entirely conceivable that Douglass' most important scientific contribution may lie in the cyclic hypotheses formulated during the last decade of his life.

Douglass received numerous honors throughout his career. In 1908, he was awarded the honorary degree of Doctor of Science by Trinity College and twenty years later the University of Arizona paid tribute in similar fashion. He was the recipient of an award by the Research Corporation of New York in 1931 and both the Society for American Archaeology and the American Anthropological Association recognized his scientific contributions with honorary resolutions passed in 1956. One measure of his standing is indicated by the many philanthropic organizations which supported his work. The Carnegie Institution of Washington, for example, in which he held the title of Research Associate from 1925 to 1938, contributed generously to his researches during the 1920's and 30's and other institutions are frequently cited for their help throughout his publications. He also had been elected to such honorary societies as Phi Kappa Phi, Psi Upsilon, Sigma Xi, and Phi Beta Kappa, at one time serving as President of the Arizona Chapters of the latter two.

His membership in professional societies reflects both the wide range of his interests and the high esteem in which he was held by his scientific colleagues. At various times, he belonged to the Royal Astronomical Society (Fellow), American Association for the Advancement of Science (Fellow and President of the Southwestern Division in 1921), American Philosophical Society, American Meteorological Society (Fellow and Vice-President in 1924-1925), Southern California Academy of Science (honorary member), Arizona Arhaeological and Historical Society (Vice-President in 1923 and President in 1929-1930), American Astronomical Society, Geographical Union, and Astronomical Society of the Pacific. In addition, he served as President of the Tree-Ring Society from its inception in 1935 until his retirement in 1958 and acted as Editor-in-chief of the Tree-Ring Bulletin for most of those years. Douglass was also an honorary life member of the National Geographic Society, a Rotarian, and a $33^{\circ}$ Scottish Rite Mason.

That Douglass was an internationally famous scientist who brought great distinction to the University of Arizona is acknowledged by all. That he displayed a warmth and humaneness typical of a truly great man is known to everyone who came in contact with him. That he was an exceptional and inspirational man is attested by his associates and students. And as for his contribution to tree-ring research, perhaps the most realistic way of paying proper tribute to Douglass is to simply state that to his colleagues the man and the science will always remain synonymous.

\section{BIBLIOGRAPHY}

\section{2}

Indications of a Rainy Period in Southern Peru. Science, Vol. 20, No. 507, pp. 231-232.

\section{4}

Swift's Comet, 1892. Astronomy and Astro-Physics, June.

Gegenschein Observations. Popular Astronomy, September.
The Polar Cap of Mars. Astronomy and Astro-Physics, No. 129.

Forms of Jupiter's Satellites. Popular Astronomy, May.

\section{5}

A Cloud-Like Spot on the Terminator of Mars. Astrophysical Journal, Vol. 1, No. 2, pp. 127-130. 
The Study of Atmospheric Currents by the Aid of Large Telescopes and the Effect of Such Currents on the Quality of the Seeing. American Meteorological Journal, Vol. 11, No. 11, pp. 395-413.

A Combination Telescope and Dome. Astrophysical Journal, May, pp. 401410.

The Lowell Observatory and Its Work. Popular Astronomy, May.

\section{6}

Projections on the Terminator of Mars and Martian Meteorology. Astronomische Nachrichten, Vol. 142, No. 3406, pp. 363-366, Kiel.

\section{7}

The Lowell Observatory in Mexico. Popular Astronomy, No. 39.

The "Astronomer's" Globe. Popular Astronomy, No. 42, pp. 57-62.

Atmosphere, Telescope and Observer. Popular Astronomy, June, pp. 64-84. Reprinted: Amateur Telescope-Making, Advanced, ed. A. G. Ingalls, pp. 585-604, Munn and Co., 1937.

Drawings of Jupiter's Third Satellite. Astronomische Nachrichten, Vol. 143, Kiel.

Gegenschein Observations, $1895-1896$. Popular Astronomy, August.

\section{8}

Observations of Mars, 1894. Annals of Lowell Observatory, Vol. I, Part 2, pp. 251-391.

The First Satellite of Jupiter. Astronomische Nachrichten, Vol. 146, pp. 346355, Kiel.

An Ascent of Popocatepetl. Popular Astronomy, Vol. 5, No. 10, pp. 505-508.

The Altitudes of Orizaba and Popocatepetl. Appalachia, Vol. 8, No. 4, pp. 356-361.

Effects of High-Mountain Climbing. Appalachia, Vol. 8, No. 4, pp. 361-367.

Stellar Bands in the Zodiac from Gemini to Scorpio. Popular Astronomy, April, pp. 511-513.

The Markings on Venus. Monthly Notices of the Royal Astronomical Society, Vol. 58, No. 7, pp. 382-385, London.

Scales of Seeing. Popular Astronomy, June.

The Present Rotation-Period of the First Satellite of Jupiter and Its Change in Form and Period Since 1892. Astronomical Journal, No. 441, pp. 69-70.

\section{9}

The Effect of Mountains on the Quality of the Atmosphere. Popular Astronomy, No. 67, pp. 354-365.
A Summary of Planetary Work at the Lowell Observatory and the Conditions Under Which It Has Been Performed. Popular Astronomy, February.

Mars. Popular Astronomy, March.

\section{0}

Observations of Jupiter and Mars. Annals of Lowell Observatory, Vol. 2, Quarto.

Photographs of the Zodiacal Light. Popular Astronomy, No. 74.

An Hypothesis Regarding the Surface Markings of Jupiter. Popular Astronomy, No. 79, pp. 473-475.

\section{1}

Montezuma's Well and the Soda Spring, Arizona. Land of Sunshine, Vol. 14 No. 4, pp. 290-299.

Photographs of the Zodiacal Light. $P u b-$ lications of the Astronomical Society of the Pacific, Vol. 13, No. 78, pp. 47-48.

Nova Persei. Popular Astronomy, May.

\section{3}

A New Almucantar. Popular Astronomy, Vol. 11, No. 5, pp. 252-254.

The Seeing at Flagstaff. Report of the Committee on Southern and Polar Observatories. Carnegie Institution, December.

\section{7}

Is Mars Inhabited? Harvard Illustrated Magazine, Vol. 8, No. 6, pp. 116-118.

Illusions of Vision and the Canals of Mars. Popular Science Monthly, Vol. 70, pp. 464-474.

Boating Down the Colorado. University of Arizona Monthly, Vol. 8, No. 1, pp. $1-5$.

1909

Weather Cycles in the Growth of Big Trees. Monthly Weather Review, No. 37, pp. 225-237.

The Crescentic Dunes of Peru. Appalachia, Vol. 12, No. 1, pp. 34-45.

\section{0}

Drawings of Comet a, 1910. Popular Astronomy, Vol. 18, No. 3, pp. 162-163.

\section{4}

A Method of Estimating Rainfall by the Growth of Trees. The Climatic Factor, by Ellsworth Huntington, pp. 101-122, Carnegie Institution of Washington, Publication 192. Reprinted: American Geographical Society Bulletin 46, No. 5, pp. 321-335.

A Photographic Periodogram of the SunSpot Numbers. Astrophysical Journal, Vol. 40, No. 3, pp. 326-331. 
1915

An Optical Periodograph. Astrophysical Journal, Vol. 41, No. 3, pp. 173-186.

\section{6}

Zodiacal Light and Counterglow and the Photography of Large Areas and Faint Contrasts. Journal of the Royal Photographic Society of Great Britain, December, London.

The Callender Sunshine Recorder and Some of the World-Wide Problems to Which This Instrument Can Be Applied. Publication of the Second PanAmerican Scientific Congress, Sec. 2, pp. 570-579.

Twilight Phenomena in Arizona, September to December, 1916. Monthly Weather Review, Vol. 44, pp. 625-628.

\section{7}

Climatic Records in the Trunks of Trees. American Forestry, Vol. 23, No. 288, pp. 732-735.

\section{8}

The Steward Observatory of the University of Arizona. Publications of the Astronomical Society of the Pacific, No. 178.

\section{9}

An Automatic Optical Periodograph (abstract). Publications of the Astronomical Society of the Pacific, June.

Climatic Cycles and Tree-Growth, Vol. I. Carnegie Institution of Washington, Publication 289.

1920

Evidence of Climatic Effects in the Annual Rings of Trees. Ecology, Vol. 1, No. 1, pp. 24-32.

\section{1}

Dating Our Prehistoric Ruins. Natural History, Vol. 21, No. 1, pp. 27-30.

Indications of Seasonal Variation of Weather in the Growth Rings of Trees. Journal of Electricity and Western Industry, Vol. 46, No. 10, pp. 510-511.

The Aurora of May 14, 1921. Science, Vol. 54, No. 1383 , p. 14.

Notes on Atmospheric Conditions at Tucson, Arizona, 1909-1920. Popular Astronomy, Vol. 29.

Dr. R. B. von KleinSmid: President of The University of Arizona, 1914-1921. The Arizona Teacher and Home Journal, December, pp. 12-16.
1922

Some Aspects of the Use of the Annual Rings of Trees in Climatic Study. Scientific Monthly, Vol. 15, No. 1, pp. 5-22. Reprinted: (Abstract) Science, Vol. 55, No. 1429, 1922; Smithsonian Report for 1922, Publication 2731, pp. 223-239, 1924.

A Recording Micrometer. Science, Vol. 55, No. 1429.

Some Topographic and Climatic Characters in the Annual Rings of the Yellow Pines and Sequoias of the Southwest. Proceedings of the American Philosophical Society, Vol. 61, No. 2, pp. 117-122.

Orientation of Prehistoric House Outlines Near Bear Canyon, Tucson, Arizona. With H. B. Leonard. Science, Vol. 55 , No. 1429.

\section{3}

Conclusions from Tree-Ring Data. A Supplement to the Geographical Review, Vol. 13, No. 4, pp. 659-661. Reprinted: Reports of the Conferences on Cycles, Carnegie Institution of Washington, pp. 5-6, 1929.

General Methods in the Advance of Cycle Studies. A Supplement to the Geographical Review, Vol. 13, No. 4, pp. 674-676. Reprinted: Reports of the Conferences on Cycles, Carnegie Institution of Washington, pp. 20-21, 1929.

Dedication of Steward Observatory, Historical Address. The Inaugural Bulletin, The University of Arizona, pp. 54-59.

University of Arizona Eclipse Expedition, Port Libertad, Mexico, Sept. 10, 1923. Popular Astronomy, Vol. 31, No. 10.

1924

The University of Arizona Eclipse Expedition, Port Libertad, Sonora, Mexico, September 10, 1923. Publications of the Astronomical Society of the Pacific, Vol. 36, No. 212, pp. 170-184.

Note on Certain Cloud Forms Observed at Tucson August 18, 1924. Monthly Weather Review, December.

\section{5}

Tree Rings and Climate. Scientific Monthly, Vol. 21, No. 1, pp. 95-99.

Notes on Certain Biological Cycles Apparently Related to Solar Activity (abstract). Bulletin of the American Meteorological Society, Vol. 6, p. 129.

Phi Kappa Phi Installation Address. Phi Kappa Phi Journal, Vol. 5, No. 4, pp. 134-136. 
1926

Photograph of Shadow Bands. Astrophysical Journal, Vol. 63, No, 3, pp. 188-190.

The Significance of Honor Societies. Phi Kappa Phi Journal, Vol. 6, No. 1, pp. 3-7.

1927

Solar Records in Tree Growth. Science, Vol. 65, No, 1679, pp, 220-221. Reprinted: Journal of the Royal Astronomical Society of Canada, Vol, 21, pp. 277-280, 1927, Toronto.

Two Sciences, Atlantic Monthly, October, pp. 488-491.

\section{8}

Climate and Trees. Nature Magazine, Vol, 12, No. 1, pp, 51-53.

Climatic Cycles and Tree Growth, Vol. II. Carnegie Institution of Washington, Publication 289.

\section{9}

Cycles in Tree Growth: the Cyclograph. Reports of the Conferences on Cycles, Carnegie Institution of Washington, pp. 34-41.

New Cyclograph Giving Graphic Interference Patterns. Pan-American Geologist, Vol. 51, No. 5, pp. 354-356.

The Secret of the Southwest Solved by Talkative Tree Rings, National Geographic Magazine, Vol. 56, No. 6, pp. 736-770. Extract: Source Book in Anthropology, by A. L. Kroeber and T, T. Waterman, pp. 177-187, Harcourt Brace, New York, 1931.

\section{0}

Past Changes in Climate in Relation to Settlements in the New World (abstract). Pan-American Geologist, Vol. 54 , p. 318.

Climatological Research. Carnegie Institution of Washington Year Book No. 29, 1929-1930, pp. 247-248.

\section{1}

Trees and Droughts in Arizona. Professional Engineer, Vol. 16, No. 6, pp. $14,26$.

Climatological Researches. Carnegie Institution of Washington Year Book No. 30, 1930-1931, pp. 278-280.

Tree Growth and Solar Cycles. Third Report of the Commission on Solar and Terrestrial Relationships, International Research Council, pp. 45-47, London.
Tree Rings and Dating of Southwestern Prehistoric Ruins (abstract), Proceedings of the 158th Meeting, San Francisco Section, American Society of Civil Engineers, Vol. 28, No. 4, pp. 2-4.

La Chronologie des Pueblos, Revue Archéologique, pp. 117-120, Paris.

\section{2}

Tree Rings and Their Relation to Solar Variations and Chronology. Smithsonian Report for 1931, Publication 3152, pp. 304-312.

Climatological Researches. Carnegie Institution of Washington Year Book No. 31, 1931-1932, pp. 217-219.

\section{3}

Climatological Researches. Carnegie Institution of Washington Year Book No. 32, 1932-1933, pp. 208-211.

Evidences of Cycles in Tree Ring Records, Proceedings of the National Academy of Sciences, Vol. 19, No. 3, pp. 350-360. Reprinted: "Symposium on Climatic Cycles. National Academy of Sciences, Washington, D.C., April 26, 1932", 1933.

Tree Growth and Climatic Cycles. The Scientific Monthly, Vol. 37, pp. 481495. Reprinted: Carnegie Institution of Washington, Supplementary Publications, No. 9, pp. 1-15, 1934.

\section{4}

Editorial. Tree-Ring Bulletin, Vol. 1, No. 1, pp. 2-3.

Accuracy in Dating-I. Tree-Ring Bulletin, Vol. 1, No. 2, pp. 10-11.

Climatological Researches. Carnegie Institution of Washington Year Book No. 33, 1933-1934, pp. 196-198.

\section{5}

Reading Tree-Rings. Arizona Alumnus, Vol. 12, No. 4, pp. 5, 13.

Climatological Researches. Carnegie Institution of Washington Year Book No. 34, 1934-1935, pp, 215-219.

Dating Pueblo Bonito and Other Ruins of the Southwest. National Geographic Society, Contributed Technical Papers, Pueblo Bonito Series, No. 1 ,

Accuracy in Dating-II: the Presentation of Evidence. Tree-Ring Bulletin, Vol, 1 , No. 3, pp. 19-21.

Estimated Ring Chronology - I: 1800 1934. Tree-Ring Bulletin, Vol, 1, No, 4, p. 27.

Estimated Ring Chronology - II: 16501800. Tree-Ring Bulletin, Vol, 1, No. $4, \mathrm{p}, 27$. 
Estimated Ring Chronology-III: 15001650. Tree-Ring Bulletin, Vol. 2, No. 1, p. 6.

Estimated Ring Chronology-IV: 1350 1500. Tree-Ring Bulletin, Vol, 2, No. 2 , p. 13.

Estimated Ring Chronology - V: 12001350. Tree-Ring Bulletin, Vol. 2, No. 2, p. 14.

Estimated Ring Chronology-VI: 10501200. Tree-Ring Bulletin, Vol. 2, No. 2, p. 15.

Estimated Ring Chronology-VII: 9001050. Tree-Ring Bulletin, Vol. 2, No. 2, p. 16.

1936

Estimated Ring Chronology-VIII: 750900. Tree-Ring Bulletin, Vol. 2, No. 3, p. 24.

Climatological Research. Carnegie Institution of Washington Year Book No. 35, 1935-1936, pp. 227-230.

Climatic Cycles and Tree Growth, Vol. III. Carnegie Institution of Washington, Publication 289.

The Central Pueblo Chronology. TreeRing Bulletin, Vol. 2, No. 4, pp. 29-34.

Estimated Ring Chronology - IX: 600750. Tree-Ring Bulletin, Vol. 3, No. 2, p. 16.

\section{7}

Typical Ring Record From Chaco Canyon: 700 to $850, \mathrm{CK}-331$. Tree-Ring Bulletin, Vol. 3, No. 3, pp. 20-21.

Note on Kapteyn's Tree-Ring Work. In: Some Early Papers on Tree-Rings, by W. S. Stallings and Edmund Schulman, Tree-Ring Bulletin, Vol. 3, No. 4, pp. 27-29.

Tree-Ring Work, 1937. Tree-Ring Bulletin, Vol. 4, No. 1, pp. 3-6.

Tree Rings and Chronology. University of Arizona Bulletin, Vol. 8, No. 4, Physical Science Series No. 1.

Climatological Research. Carnegie Institution of Washington Year Book No. 36, 1936-1937, pp. 228-230.

Foreword. Principles and Methods of Tree-Ring Analysis, by Waldo $\mathrm{S}$. Glock, pp. vii-viii, Carnegie Institution of Washington, Publication 486.

\section{8}

Estimated Tree-Ring Chronology: $450-$ 600 A.D. Tree-Ring Bulletin, Vol. 4, No. 3, p. 8.

Estimated Tree-Ring Chronology: 300450 A.D. Tree-Ring Bulletin, Vol. 5, No. 1, p. 8.

Southwestern Dated Ruins: V. TreeRing Bulletin, Vol. 5, No. 2, pp. 10-13.

Historical Climatology. Carnegie Institution of Washington Year Book No. 37, 1937-1938, pp. 235-237.
1939

Estimated Tree-Ring Chronology: 150300 A.D. Tree-Ring Bulletin, Vol. 5, No. 3, pp. 18-20.

Notes on Beam Dating by Sap-Heart Contact. Tree-Ring Bulletin, Vol. 6, No. 1, pp. 3-6.

Steward Observatory. Annual Report of The University of Arizona, for the Fiscal Year Ended June 30, 1939.

Typical Site of Trees Producing the Best Crossdating. Tree-Ring Bulletin, Vol. 6, No. 2, pp. 10-11.

Southwestern Photographic Ring Sequence. U. S. Department of Agriculture Bibliofilm Service. American Documentation Institution, Document No. 1298, Washington.

1940

Dendrochronology and Studies in "Cyclics", University of Pennsylvania Bicentennial Conference, October, pp. 57-79.

Examples of Spiral Compression Wood. Tree-Ring Bulletin, Vol. 6, No. 3, pp. 21-22.

Compression Wood and the Recent Chronology in Mesa Verde Firs. TreeRing Bulletin, Vol. 6, No. 3, pp. 23-24.

Editorial: A Bibliography. Tree-Ring Bulletin, Vol. 6, No. 4, pp. 26-27.

Estimated Ring Chronology 150-1934 A.D. Tree-Ring Bulletin, Vol. 6, No. 4 , insert.

Notes on the Technique of Tree-Ring Analysis, I. Tree-Ring Bulletin, Vol. 7 , No. 1.

1941

Notes on the Technique of Tree-Ring Analysis, II. Tree-Ring Bulletin, Vol. 7, No. 4.

Age of Forestdale Ruin Excavated in 1939. Tree-Ring Bulletin, Vol. 8, No. 1 , pp. $7-8$.

Notes on the Technique of Tree-Ring Analysis, III. Tree-Ring Bulletin, Vol. 8, No. 2.

Crossdating in Dendrochronology. Journal of Forestry, Vol. 39, No. 10, pp. $825-831$.

\section{2}

Crossdating at Mesa Verde National Park. Journal of Forestry, Vol. 40, No. 4, pp. 347-348.

Checking the Date of Bluff Ruin, Forestdale: A Study in Technique. TreeRing Bulletin, Vol. 9, No. 2, pp. 2-7.

\section{3}

Advances in Dendrochronology, 1943. Tree-Ring Bulletin, Vol. 9, No. 3.

Notes on the Technique of Tree-Ring Analysis, IV: Practical Instruments. Tree-Ring Bulletin, Vol. 10, No. 1. 
Notes on the Technique of Tree-Ring Analysis, V: Practical Instruments. Tree-Ring Bulletin, Vol. 10, No. 2.

\section{4}

Tabulation of Dates for Bluff Ruin, Forestdale, Arizona. Tree-Ring Bulletin, Vol. 11, No. 2.

Tree-Ring and Climatic Cycles. Phi Kappa Phi Journal, Vol. 24, No. 3, pp. 81-85.

Laboratory of Tree-Ring Research. Phi Kappa Phi Journal, Vol. 24, No. 3, pp. 86-87.

Astronomical Studies. Phi Kappa Phi Journal, Vol. 24, No. 3, pp. 88-89.

\section{5}

Foreword. Tree-Ring Hydrology of the Colorado River Basin, by Edmund Schulman, p. 4, University of Arizona Bulletin, Vol, 16, No. 4, Laboratory of Tree-Ring Research Bulletin No. 2.

Survey of Sequoia Studies, I. Tree-Ring Bulletin, Vol. 11, No. 4.

Survey of Sequoia Studies, II. Tree-Ring Bulletin, Vol. 12, No. 2.

\section{6}

Sequoia Survey, III: Miscellaneous Notes. Tree-Ring Bulletin, Vol. 13, No. 1, pp. 5-8.

Precision of Ring Dating in Tree-Ring Chronologies. University of Arizona Bulletin, Vol. 8, No. 3, Laboratory of Tree-Ring Research Bulletin No. 3.

Researches in Dendrochronology. University of Utah Bulletin, Vol. 37, No. 2, Biological Series, Vol. 10, No. 1.
1947

Photographic Tree-Ring Chronologies and the Flagstaff Sequence. TreeRing Bulletin, Vol. 14, No. 2.

\section{9}

Note on the Early Durango Collections. Tree-Ring Bulletin, Vol. 15, No. 4, p. 24.

A Superior Sequoia Ring Record. TreeRing Bulletin, Vol. 16, No. 1, pp. 2-6.

$$
1950
$$

Introduction: Our Friend, Byron Cummings. For the Dean, Hohokam Museums Association, Tucson, and Southwestern Monuments Association, Santa Fe.

A Superior Sequoia Ring Record, II A.D. 870-1209. Tree-Ring Bulletin, Vol. 16, No. 3, p. 24.

A Superior Sequoia Ring Record, III. A.D. 360-886. Tree-Ring Bulletin, Vol. 16, No. 4, pp. 31-32.

\section{1}

Foreword. A Summary of Tree-Ring Dates from Some Southwestern Archaeological Sites, by T. L. Smiley, p. 4, University of Arizona Bulletin, Vol. 22, No. 4, Laboratory of TreeRing Research Bulletin No. 5.

A Superior Sequoia Ring Record, IV. 7 B.C.-A.D. 372. Tree-Ring Bulletin, Vol. 17, No. 3, pp. 23-24.

A Superior Sequoia Ring Record, V. 271 B.C.-1 B.C. Tree-Ring Bulletin, Vol. 17, No. 4, pp. 31-32. 